\title{
A Case of Burkitt's Lymphoma in a Child Presenting with Obstructive Jaundice and Requiring Surgical Intervention
}

\author{
Amandeep Kaur ${ }^{1}$ Payal Malhotra ${ }^{1}$ Sandeep Jain ${ }^{1}$ Gauri Kapoor ${ }^{1}$ \\ ${ }^{1}$ Department of Pediatric Hematology and Oncology, Rajiv Gandhi \\ Address for correspondence Gauri Kapoor, MD, PhD, Department \\ of Pediatric Hematology and Oncology, Rajiv Gandhi Cancer \\ Institute and Research Centre, Sector 5, Rohini, New Delhi 110085, \\ India (e-mail: kapoor.gauri@rgcirc.org; kapoor.gauri@gmail.com).
}

\begin{abstract}
Burkitt's lymphoma is a high-grade B non-Hodgkin lymphoma (NHL) and rarely presents with jaundice. We discuss the case of a 6-year-old male child presenting with fever, jaundice, and abdominal distention. Computed tomographic (CT) scan of the abdomen revealed a heterogeneous lymph node mass at the pancreatic head with intrahepatic biliary dilation. Serum bilirubin was $26 \mathrm{mg} / \mathrm{dL}$ with direct fraction of $12.4 \mathrm{mg} / \mathrm{dL}$. Biopsy and staging confirmed the diagnosis of Burkitt's lymphoma stage 3 , group B. In view of hyperbilirubinemia, chemotherapeutic drugs doses were modified and rituximab was added. Persistent jaundice necessitated percutaneous biliary drainage so that chemotherapy could be continued. Despite complete response, jaundice

Keywords

- biliary drainage

- non-Hodgkin

lymphoma

- obstructive jaundice and biliary dilatation remained. Hence, a side-to-side choledochoduodenostomy was performed after which the liver function normalized. Presently the child is well. NHL is a chemosensitive disease. If the serum bilirubin does not normalize quickly, biliary drainage is essential to allow administration of curative chemotherapy and prevent chronic liver damage.
\end{abstract}

\section{Introduction}

Burkitt's lymphoma is a high-grade B non-Hodgkin lymphoma (NHL) with a high proliferative index and is exquisitely sensitive to chemotherapy. Jaundice is a rare presentation of $\mathrm{NHL}$ and has been reported in approximately 0.4 to $3 \%$ of pediatric cases. ${ }^{1}$ In most instances, hyperbilirubinemia occurs due to external compression of biliary system or infiltration of hepatic parenchyma. Hence jaundice usually resolves with administration of chemotherapy and surgical drainage is rarely required.

We report the case of a 6-year-old boy, with abdominal Burkitt's lymphoma presenting with marked obstructive jaundice and discuss associated challenges in administering optimum chemotherapy as well as need for surgical intervention.

\section{Case Report}

A 6-year-old male child presented with a 2-month history of intermittent fever, yellowish discoloration of eyes, highcolored urine, and distension of the abdomen. He was presumptively treated for viral hepatitis with indigenous medicines. Abdominal ultrasound scans followed by needle aspiration were suggestive of a malignancy. Thereafter the child was referred to us for further management.

On examination, the child was conscious, oriented, deeply icteric, pale, emaciated (weight $<5$ th percentile for age), and hemodynamically stable. There were no lymphadenopathy, pedal edema, skin rash, or signs of liver failure. Systemic examination revealed a distended abdomen with a firm, nontender mass in the epigastric region extending to the right hypochondrium and hypogastric region. Rest of the examination was unremarkable.
DOI https://doi.org/ $10.1055 / \mathrm{s}-0038-1676764$ ISSN 2454-6798.
License terms

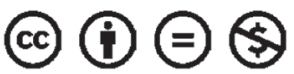


The patient was thoroughly investigated with laboratory and imaging studies ( - Table $\mathbf{1}$ ). Computed tomography (CT) of the abdomen revealed a large nodal mass in the region of the pancreatic head causing common bile duct obstruction (-Fig. 1).

A transduodenal endoscopic biopsy confirmed the diagnosis, and after staging workup, a final diagnosis of primary abdominal Burkitt's lymphoma, stage 3 (Murphy's staging), group B (LMB) was made. ${ }^{2-4}$ Tumor lysis prophylaxis was initiated, and chemotherapy as per LMB-96 protocol was planned. The chemotherapy schedule for group B disease includes cytoreductive phase COP (cyclophosphamide, vincristine, prednisolone), followed by two cycles each of COPADM (COP, Adriamycin, and methotrexate) and CYM (cytarabine and methotrexate) and one cycle of maintenance COPADM. In view of the elevated serum bilirubin, doses of vincristine, Adriamycin, and methotrexate were withheld as per the guidelines of the protocol and the NCCN (National Comprehensive Cancer Network). ${ }^{5}$ Because of compromise in the chemotherapy schedule, rituximab was added to the initial three cycles (R-COP and R-COPADMx2) and CYM was substituted with CYVE (cytarabine, etoposide).

Clinically, the patient responded well to treatment; however, high levels of serum bilirubin persisted. Two attempts at endoscopic retrograde cholangiopancreatogram (ERCP) were unsuccessful after which percutaneous biliary drainage (PBD) was done. The catheter could not be negotiated beyond the CBD. This reduced the bilirubin from 19 to $7.2 \mathrm{mg} / \mathrm{dL}$ and enabled us to give consolidation therapy. Response evaluation after three cycles of chemotherapy revealed complete response. However, the clinical course of the patient was quite turbulent with multiple episodes of febrile neutropenia during which the hepatopathy worsened. After completion of chemotherapy courses, hyperbilirubinemia and biliary dilatation persisted. Two months later, a side-to-side choledochoduodenostomy was performed. Presently the child is 4 years off therapy and disease free, with normal liver functions.

\section{Discussion}

Jaundice is a known though uncommon initial presentation of pediatric NHL. ${ }^{6}$ Various postulated mechanisms include direct involvement of the liver, extrinsic lymph nodal compression, intrahepatic cholestasis, and toxic hepatitis due to drugs and or hemolysis. The porta-hepatis and hepatopancreaticoduodenal regions, where the bile ducts are less mobile, are particularly vulnerable to compression and obstructive jaundice. ${ }^{1}$ In this case as well, extrahepatic biliary obstruction was due to enlarged lymph nodes at the porta hepatis. The transaminitis might have been due to drugs administered to the patient prior to diagnosis and/or possible infiltration by lymphoma. This along with episodes of febrile neutropenia during chemotherapy treatment may have led to

Table 1 Initial laboratory parameters

\begin{tabular}{|c|c|}
\hline Test & Parameter \\
\hline Hemogram & $\begin{array}{l}\text { Hemoglobin } 8.3 \mathrm{~g} / \mathrm{dL} \text {, total leukocyte count } 2.43 \times 10^{4} / \mu \mathrm{L} \text {, neutrophils } 43 \% \text {, lymphocytes } \\
52 \% \text {, monocytes } 5 \% \text {, platelet } 233 \times 10^{3} / \mu \mathrm{L}\end{array}$ \\
\hline Liver function test & $\begin{array}{l}\text { Total serum bilirubin } 26 \mathrm{mg} / \mathrm{dL} \text { (normal range: } 0.3-1.2 \mathrm{mg} / \mathrm{dL} \text { ), direct serum bilirubin } \\
12.4 \mathrm{mg} / \mathrm{dL} \text { (normal range: } 0.0-0.2 \mathrm{mg} / \mathrm{dL} \text { ), SGOT } 250 \mathrm{U} / \mathrm{L} \text { (normal range: } 5-40 \mathrm{U} / \mathrm{L} \text { ), } \\
\text { SGPT } 250 \mathrm{U} / \mathrm{L} \text { (normal range: } 5-40 \mathrm{U} / \mathrm{L} \text { ), alkaline phosphatase } 115 \mathrm{U} / \mathrm{L} \text { (normal range: } \\
30-120 \mathrm{U} / \mathrm{L} \text { ), serum gamma glutamyl transferase } 470 \mathrm{U} / \mathrm{L} \text { (normal range: }<50 \mathrm{U} / \mathrm{L} \text { ), total } \\
\text { protein } 4 \mathrm{~g} / \mathrm{dL} \text { (normal range: } 6.6-8.3 \mathrm{~g} / \mathrm{dL} \text { ), albumin } 2.9 \mathrm{~g} / \mathrm{dL} \text { (normal range: } 3.5-5.2 \mathrm{~g} / \mathrm{dL} \text { ) }\end{array}$ \\
\hline Renal function test & $\begin{array}{l}\text { Blood urea } 26 \mathrm{mg} / \mathrm{dL} \text { (normal range: } 10-40 \mathrm{mg} / \mathrm{dL} \text { ), serum creatinine } 0.3 \mathrm{mg} / \mathrm{dL} \text {, (normal } \\
\text { range: } 0.2-1.2 \mathrm{mg} / \mathrm{dL} \text { ), serum uric acid } 3.9 \mathrm{mg} / \mathrm{dL} \text { (normal range: } 3.5-7.2 \mathrm{mg} / \mathrm{dL} \text { ), serum } \\
\text { sodium } 138 \mathrm{mEq} / \mathrm{L} \text { (normal range: } 136-145 \mathrm{mEq} / \mathrm{L} \text { ), serum potassium } 3.5 \mathrm{mEq} / \mathrm{L} \text { (normal } \\
\text { range: } 3.5-5.1145 \mathrm{mEq} / \mathrm{L} \text { ), lactate dehydrogenase } 466 \mathrm{U} / \mathrm{L} \text { (normal range: } 100-248 \mathrm{U} / \mathrm{L} \text { ) }\end{array}$ \\
\hline Serum amylase and lipase & Normal \\
\hline Coagulation & $\begin{array}{l}\text { PT } 12.7 \text {, second INR } 1.29 \\
\text { PT reference range ( } 11.8-15.4 \text { seconds) }\end{array}$ \\
\hline Viral serology and PCR & HAV, HBsAg, HCV, EBV, and CMV were negative \\
\hline Tissue biopsy & $\begin{array}{l}\text { Histopathology, suggestive of round blue cell tumor; immunohistochemistry positive for } \\
\text { CD10 and CD20 and negative for CD3/TdT with } \mathrm{K}_{\mathrm{i}} \text { proliferation index }>99 \%\end{array}$ \\
\hline $\begin{array}{l}\text { Bone marrow aspirate and } \\
\text { biopsy }\end{array}$ & Show normal marrow elements, no lymphoma deposit \\
\hline Cerebrospinal fluid & Cytology-no atypical cells, sugar 68 mg\%, protein 33 mg\% \\
\hline CT abdomen & $\begin{array}{l}\text { CT of abdomen revealed: multiple enlarged lymph nodes in celiac, peripancreatic, } \\
\text { aortocaval, and left para-aortic region. There was a large nodal mass measuring } 6 \times 6 \mathrm{~cm} \text {, } \\
\text { in the region of the pancreatic head, abutting the duodenum and causing abrupt cutoff of } \\
\text { the distal CBV }\end{array}$ \\
\hline
\end{tabular}

Abbreviations: CBD, common bile duct; CBV, cerebral blood volume; CMV, cytomegalovirus; $C T$, computed tomography; EBV, Epstein-Barr virus; HAV, hepatitis A virus; HBsAg, hepatitis B surface antigen; HCV, hepatitis C virus; PCR, polymerase chain reaction; PT, prothrombin time; SGOT, serum glutamate-oxaloacetate transaminase; SGPT, serum glutamic-pyruvic transaminase; TdT, terminal deoxyneucleotidyl transferase. 




Fig. 1 (A) Computed tomography of the abdomen showing large lobulated mass near pancreatic head, causing abrupt cutoff of distal common bile duct. (B) Computed tomography of abdomen showing dilated intrahepatic biliary radicals post first cycle of chemotherapy. (C) Serum bilirubin trend during treatment. (D) Percutaneous biliary drainage, catheter could not be negotiated beyond common bile duct. COP, cyclophosphamide, vincristine, prednisolone; ERCP, endoscopic retrograde cholangiopancreatogram; PTBD, percutaneous transhepatic biliary drainage; RCOP, rituximab, cyclophosphamide, vincristine, prednisolone.

infection/inflammation in the biliary system, subsequently culminating in healing by fibrosis and development of bile duct stricture.

Burkitt's lymphoma in children has excellent cure rates, and chemotherapy is the mainstay of treatment. The presence of hepatopathy poses a challenge to the treating oncologists as most of the indicated cytotoxic agents require omission or dose modification. Rituximab is a chimeric monoclonal antibody against the protein $\mathrm{CD} 20$ present on the surface of B-NHL cells. When used in combination with multiagent chemotherapy, it has been found to be efficacious in its treatment. ${ }^{7}$ Its safety profile in patients with deranged liver function prompted us to add it to our compromised chemotherapy schedule. $^{8}$

Burkitt's lymphoma is a chemotherapy sensitive disease; hence, jaundice was expected to resolve with the initiation of antilymphoma therapy. However, persistent hepatopathy necessitated a biliary drainage procedure in parallel. As two attempts at ERCP failed, PBD was done, which dramatically brought down the serum bilirubin, enabling delivery of consolidation chemotherapy in optimum doses. Various techniques for biliary decompression include external-internal drain, stent placement, or laparotomy at presentation. Although these treatments may relieve the obstruction and associated symptoms, they may cause crucial delay in definitive treatment. In a disease, as aggressive as Burkitt's lymphoma, it is equally important to avoid delay and initiate antilymphoma therapy urgently. Establishing the cause of obstructive jaundice is very critical as it determines the approach to management and influences the ability to deliver optimum therapy. In a retrospective review of 35 adult lymphoma patients with obstructive jaundice, serum bilirubin normalized in $85 \%$ of those who underwent ERCP or PBD. ${ }^{9}$ Choledochoduodenostomy was done after the completion of all planned therapy to prevent cholestatic liver damage. 


\section{Conclusion}

Obstructive jaundice is a rare initial presentation of NHL. If the serum bilirubin does not rapidly normalize with treatment, it is important to proceed with biliary drainage. Early decompression allows for optimum delivery of curative chemotherapy and prevents chronic liver damage.

\section{Funding}

None.

\section{Conflict of Interest}

None declared.

\section{References}

1 Odemiş B, Parlak E, Başar O, Yüksel O, Sahin B. Biliary tract obstruction secondary to malignant lymphoma: experience at a referral center. Dig Dis Sci 2007;52(9):2323-2332

2 Murphy SB. Classification, staging and end results of treatment of childhood non-Hodgkin's lymphomas: dissimilarities from lymphomas in adults. Semin Oncol 1980;7(3):332-339

3 Patte C, Auperin A, Gerrard M, et al; FAB/LMB96 International Study Committee. Results of the randomized international FAB/LMB96 trial for intermediate risk B-cell
non-Hodgkin lymphoma in children and adolescents: it is possible to reduce treatment for the early responding patients. Blood 2007;109(7):2773-2780

4 Cairo MS, Sposto R, Gerrard M, et al. Advanced stage, increased lactate dehydrogenase, and primary site, but not adolescent age ( $\geq 15$ years), are associated with an increased risk of treatment failure in children and adolescents with mature B-cell non-Hodgkin's lymphoma: results of the FAB LMB 96 study. J Clin Oncol 2012;30(4):387-393

5 National Comprehensive Cancer Network. Clinical Practice Guidelines in Oncology. B-Cell Lymphoma. Version 2. 2018

6 Kutluk T, Varan A, Caglar K, Güler E, Büyükpamukçu M. Management of obstructive jaundice caused by non-Hodgkin lymphoma in children. Med Pediatr Oncol 2001;36(6):669-670

7 Pillon M, Carraro E, Mussolin L, et al. Primary mediastinal large B-cell lymphoma: Outcome of a series of pediatric patients treated with high-dose methotrexate and cytarabine plus anti-CD20. Pediatr Blood Cancer 2018;65(2):65

8 Marcus R, Hagenbeek A. The therapeutic use of rituximab in non-Hodgkin's lymphoma. Eur J Haematol Suppl 2007; (67):5-14

9 Ross WA, Egwim CI, Wallace MJ, Wang M, Madoff DC, Lee JH. Outcomes in lymphoma patients with obstructive jaundice: a cancer center experience. Dig Dis Sci 2010;55(11):3271-3277 